\title{
Electrooxidation of Alkyd Resin Production Wastewater By Boren Doped Diamond Electrode
}

\author{
${ }^{1}$ Nevin Atalay Gengec, ${ }^{* 2}$ Erhan Gengec, ${ }^{3}$ Orhan Taner Can and ${ }^{4}$ Mehmet Kobya \\ ${ }^{1}$ The Bilecik Seyh Edabali University, Chemical and Process Engineering Department, Bilecik, Turkey \\ *2 Kocaeli University, Environmental Protection and Control Department, Izmit, Kocaeli, Turkey \\ ${ }^{3}$ Bursa Technical University, Department of Environmental Engineering, Bursa, Turkey \\ ${ }^{4}$ Gebze Technical University, Department of Environmental Engineering, Gebze, Kocaeli, Turkey
}

\begin{abstract}
:
Wastewater of alkyd resin production (ARW) has low $\mathrm{pH}$ value (2.3) and high organic matters $(15,304$ $\mathrm{mg} / \mathrm{L}$ of TOC and $45,220 \mathrm{mg} / \mathrm{L}$ of COD) as well as is toxic and non-biodegradable. In addition to, it does not respond to chemical coagulation and adsorption. Thus, advance oxidation processes (AOPs) or combinations of AOPs are very important alternatives for treatment of ARW due to the advantages which they have. The purpose of this study is to investigate the treatment efficiencies of anodic electrooxidation process by boren doped diamond electrode (BDD). The effect of process parameters such as current density $\left(40-100 \mathrm{~mA} / \mathrm{cm}^{2}\right)$, operation time $(0-180 \mathrm{~min}$.) and $\mathrm{pH}$ of wastewater were investigated. The maximum removal efficiencies were obtained as $42.3 \%$ of TOC and $43.4 \%$ of COD at the $100 \mathrm{~mA} / \mathrm{cm}^{2}, 180 \mathrm{~min}$ and $\mathrm{pH}$ of 3.5. The consumed electric energy and operation cost were calculated as $169.07 \mathrm{kWh} / \mathrm{m}^{3}$ and $42.27 \mathrm{TL}$. Although as the removal ratios were not seemed very high, the removed COD and TOC values showed the potential of EO with BDD. Consequently, EO was a suitable process for the treatment of ARW; however the results showed that it must be applied with combination of other AOPs.
\end{abstract}

Key words: Alkyd Resin Production, Electro-oxidation, Boren Doped Diamond Electrode.

\section{Introduction}

Alkyd resin production wastewaters are typical examples of strong organic effluents containing 23-40 g/L COD and toxic compounds [1]. Due to this content, before discharging of the wastewater to municipal wastewater channel, it must be treated. However, physical treatments systems can not treat this wastewater because the pollutants in wastewater are the dissolve compounds. The biological treatment systems are ineffective because this wastewater is highly toxic and nonbiodegradable. In this study, various coagulants have been tried in preliminary experiments, but these coagulants have not been effective even at high doses. Due to the reason mentioned above, advanced oxidation treatment systems are likely to be effective. Inside this sytems, Electrooxidation (EO) presents a large number of advantages; (I) the oxidation of pollutants up to final products or to less toxic by-products in contrast with coagulation, membrane, filtration, and adsorption processes, (II) low oxidation time requirements, no sludge problem, non-selective to toxic and non-biodegradable material in contrast with biological oxidation processes, and (III) the addition of chemical reagents is not required (except of electrolytes or catalysts addition at low amounts) in contrast with chemical oxidation [2].

*Corresponding author: Address: Kocaeli University, Environmental Protection and Control Department, Izmit, Kocaeli, TURKEY. E-mail address: erhan.gengec@kocaeli.edu.tr, Phone:+90 2623513437. 
EO can be categorized as direct and indirect oxidation. In indirect oxidation processes, oxidizing reagents such as chlorine, hypochlorous acid, hypochlorite, hydrogen peroxide and ozone are formed at electrodes surface and then, destroy pollutants in wastewater. On the other hand, direct oxidation process involves (I) electron transfer to the pollutants and (II) the forming of hydroxyl radicals on anode's surface [3,4]. When direct and indirect oxidation are compared, direct oxidation has some advantages such as required a lower amount of chemical substance and produced no secondary contaminants [3]. The electrocatalytic activity and electrochemical stability of electrode is a key point for direct oxidation. Although several anode materials have been used in the direct oxidation, the complete mineralization of the pollutants has been possible by using high oxygen overvoltage anodes such as $\mathrm{SnO}_{2}, \mathrm{PbO}_{2}$ and boron-doped diamond (BDD) up to date [5]. The BDD electrode has been identified as an excellent non-active anode at removal of pollutants in wastewater [6] and generation of hydroxyl radical ( $\mathrm{OH}$ ) on the BDD anode surface has been reported as main removal mechanism. Due to the having inert surface and low adsorption capacity, the BDD surface interacts weakly with the ${ }^{\circ} \mathrm{OH}$. During EO with BDD, complete mineralization of pollutants in wastewater can be possible due to the physisorbed $\cdot \mathrm{OH}$ (Reaction 1 and 2, R: organic pollutants in wastewater) [7-11]

$\mathrm{M}+\mathrm{H}_{2} \mathrm{O} \rightarrow \mathrm{M}\left(\mathrm{HO}^{\bullet}\right)+\mathrm{H}^{+}+\mathrm{e}^{-}$

$\mathrm{M}\left(\mathrm{HO}^{\circ}\right)+\mathrm{R} \rightarrow \mathrm{M}+\mathrm{mCO}_{2}+\mathrm{nH}_{2} \mathrm{O}+\mathrm{H}^{+}+\mathrm{e}^{-}$

Therefore, the purposes of this study were; (I) to present the combination of EC and EO as an competitive alternative for treatment of industrial wastewater with high suspended solids, organic content and toxicity, (II) to investigate the effect of process conditions on removal efficiencies, and (III) to calculate the electrical and electrode consumption during these processes.

\section{Materials and Method}

The wastewater was taken in entrance of a alkyd resin production plant. It has a strong characterist with low $\mathrm{pH}(2.28)$ and high organic matters $(15,304 \mathrm{mg} / \mathrm{L}$ of TOC and 45,220 mg/L of COD).

EO experiments were conducted in batch mode by using an open, undivided, glass cell $(12 \times 9 \times 7$ $\mathrm{cm})$. The glass cell of $0.75 \mathrm{~L}$ capacity was surrounded by a double jacket for circulation of external thermostated water, controlled at $25 \pm 1{ }^{\circ} \mathrm{C}$.

A thin-film of BDD electrode was used in EO experiments and the effective area of the EO anodes was $36 \mathrm{~cm}^{2}$. The BDD anode was supplied by DiaCCon $\mathrm{GmbH}$. The cathode was a stainless steel sheet and the inter-electrode distance was about $1.5 \mathrm{~cm}$. All EO experiments were performed with $0.6 \mathrm{~L}$ of wastewater at $300 \mathrm{rpm}$ (Heidolp MR 3000D). $\mathrm{NaCl}$ were preferred as electrolyte and added in to the wastewater at identified quantity. The electrodes were connected to a digital DC power supply (Agilent 6675A model; $30 \mathrm{~V}, 6 \mathrm{~A}$ ) operated at galvanostatic mode and the current was held constant at desired values for each run.

TOC levels were determined by combustion of the samples at $680{ }^{\circ} \mathrm{C}$ using a non-dispersive IR source (Shimadzu, TOC-L model). COD measurements were realized by Standard Methods [12]. 
The $\mathrm{pH}$ of the sample was adjusted with $0.1 \mathrm{M} \mathrm{H}_{2} \mathrm{SO}_{4}$ or $\mathrm{NaOH}$ and measured by a $\mathrm{pH}$ meter (WTW Inolab $\mathrm{pH}$ 720). The analyses were triplicated and the average data were reported. The accuracy of these measured values for COD and TOC were calculated around $1.0 \%$.

The consumption of electrical energy $\left(\mathrm{kWh} / \mathrm{m}^{3}\right)$ were calculated in Eqn.1 from Faraday's Law [13]:

$\mathrm{ENC}=\frac{\mathrm{U} \times \mathrm{i} \times \mathrm{t}}{\mathrm{v}}$

Where $\mathrm{U}$ is cell voltage $(\mathrm{V}), \mathrm{I}$ is current $(\mathrm{A}), \mathrm{t}$ is operating time $(\mathrm{s})$ and $\mathrm{v}$ is volume $\left(\mathrm{m}^{3}\right)$ of the wastewater. The operation cost was calculated through $0.25 \mathrm{TL} / \mathrm{kWh}$.

\section{Results and discussion}

It is well known that type of electrode, initial $\mathrm{pH}(\mathrm{pHi})$, current density $\left(\mathrm{CD} ; \mathrm{A} / \mathrm{m}^{2}\right)$ and operating time (t; min.) are the major parameters which affect the removal efficiencies in EO process. Therefore, some of these parameters's effects were dealt with in this study.

\subsection{Effect of current density and operating time}

The current density (calculated by dividing of applied current by the active electrode area) is the most important driving force because it affects not only the degradation rate of the EO with BDD but also controlling the reaction rate in all electrochemical processes (bubble production rate, $\mathrm{O}_{2}$ reduction/evaluation etc.). In this study, the ARP wastewater was treated at three different $\mathrm{CD}$ as $50.0,75.0$ and $100.0 \mathrm{~mA} / \mathrm{cm}^{2}$. Although, the highest removal efficiencies were obtained as $15.2 \%$ for COD and $14.9 \%$ for TOC at $100.0 \mathrm{~mA} / \mathrm{cm}^{2}$ and $120 \mathrm{~min}$., the results were not satisfactory.

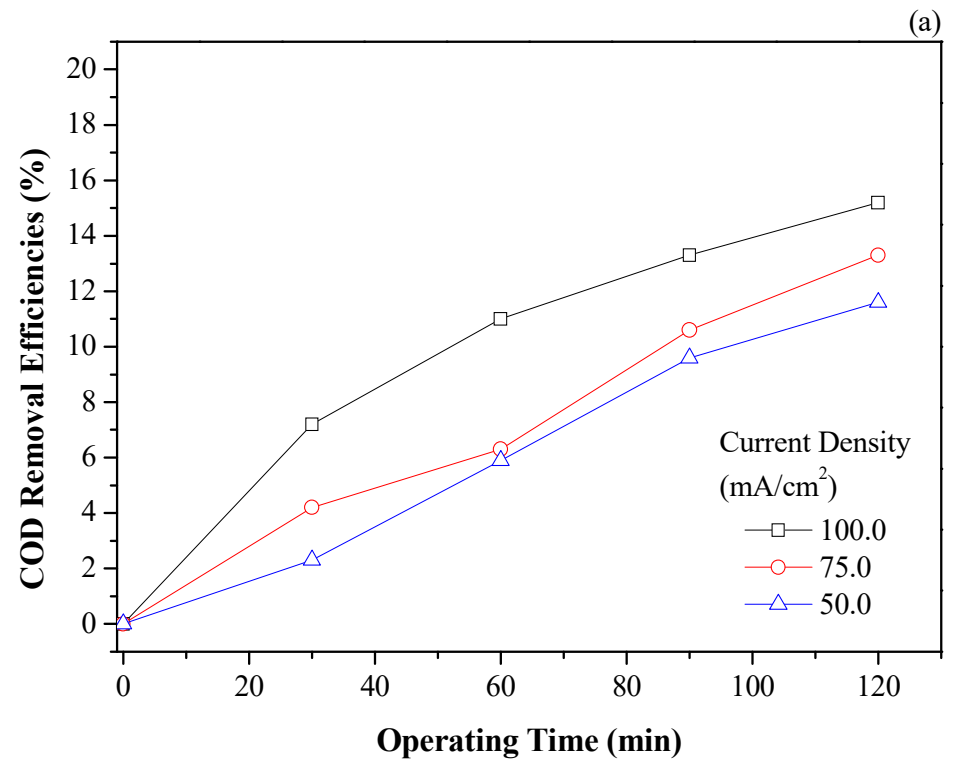




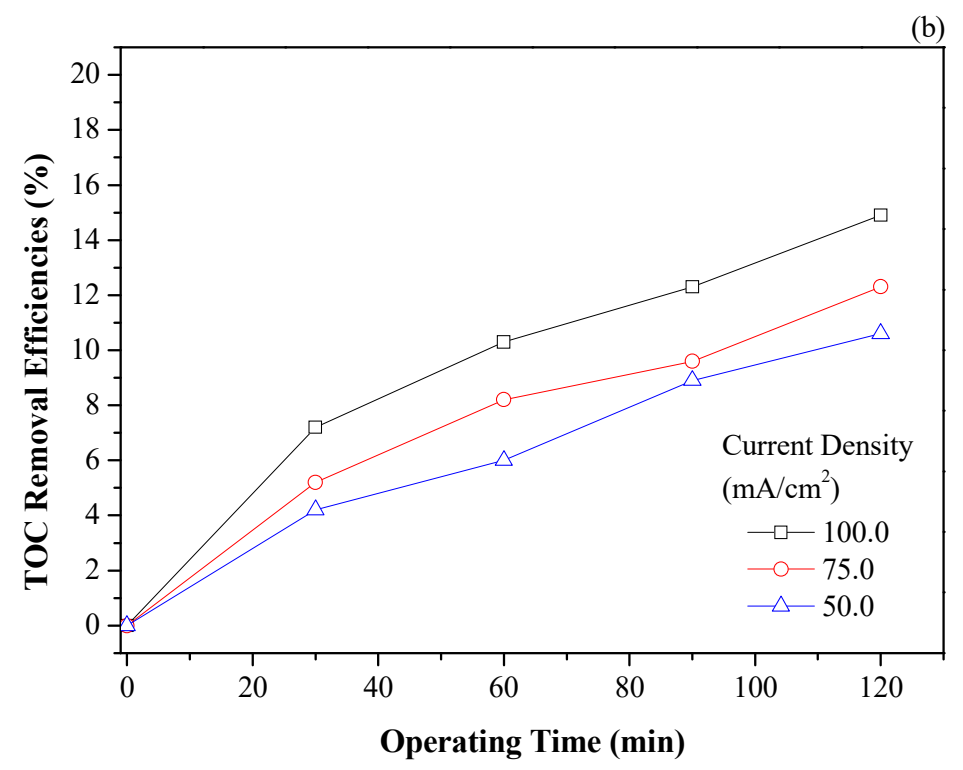

Figure 1. The effect of current density (pH: $2.3 \mathrm{~mA} / \mathrm{cm}^{2}$ and $C_{\mathrm{el}}: 5 \mathrm{~g} \mathrm{NaCl} / \mathrm{L}$ )

\subsection{Effect of initial pH and operating time}

The $\mathrm{pH}$ of wastewater affects the chemical properties of pollutants and interaction of pollutants with electrode. Thus, the effect of initial $\mathrm{pH}$ on the EO process was investigated at $\mathrm{pH}$ of $2.3,3.5$, 5.537 .5 and 9.5. Although, the best removal efficiencies were obtained as $\% 17.65$ for COD and $18.65 \%$ for TOC at $\mathrm{pH}$ of 5.5 , the optimum points were seemed as $\mathrm{pH}$ of 3.5 because high cost of $\mathrm{pH}$ arrangement.

(a)

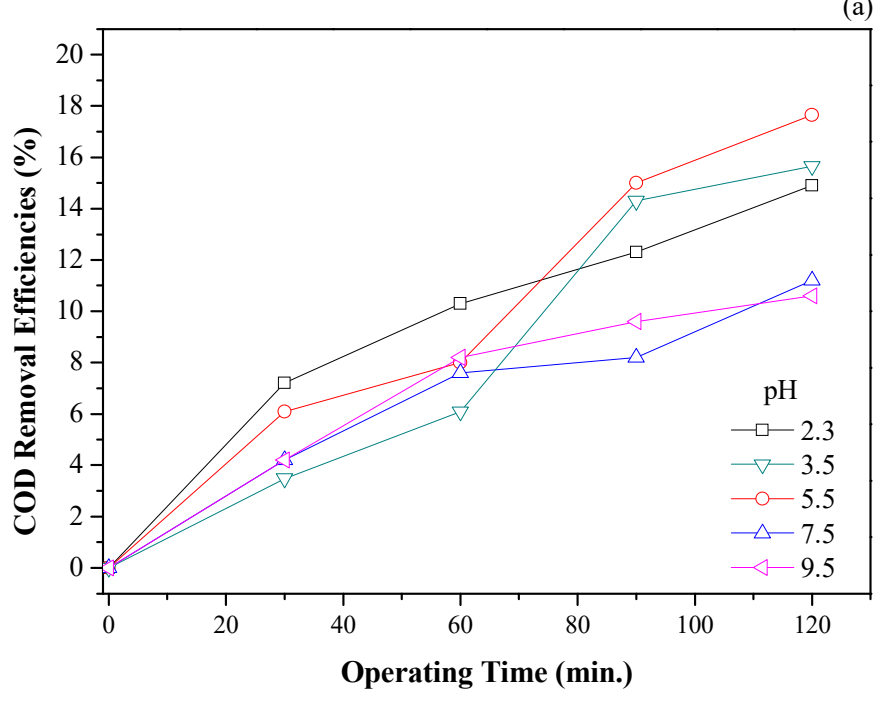




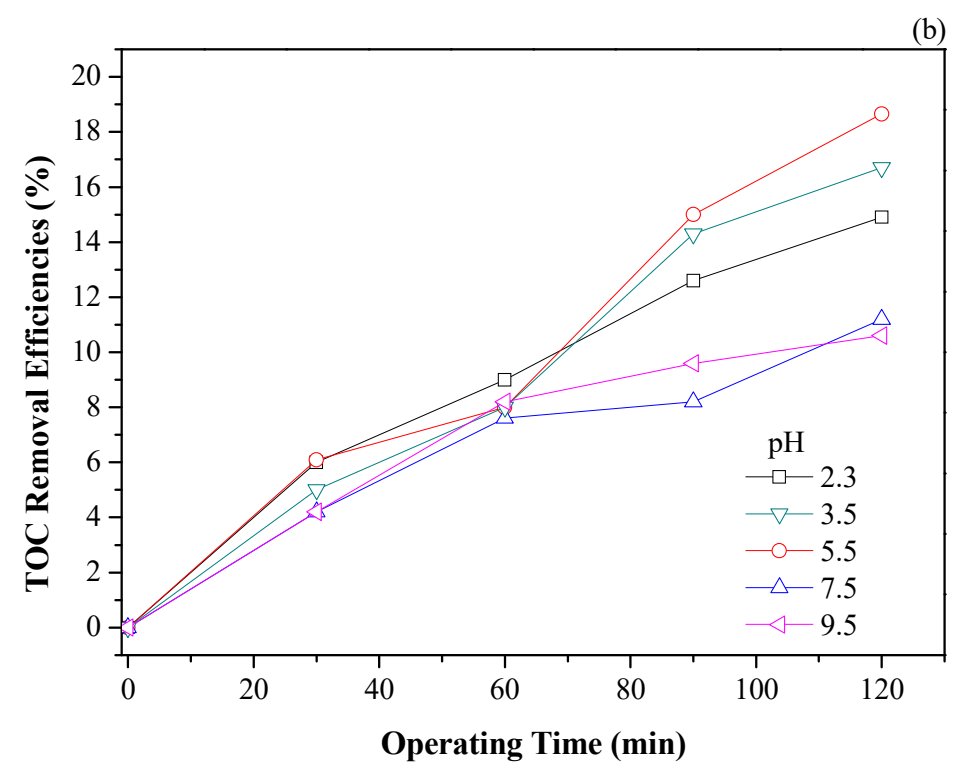

Figure 2. The effect of $\mathrm{pH}\left(\mathrm{CD}: 100 \mathrm{~mA} / \mathrm{cm}^{2}\right.$ and $\left.C_{\mathrm{el}}: 5 \mathrm{~g} \mathrm{NaCl} / \mathrm{L}\right)$

\subsection{Effect of electrolyte concentration and operating time}

The most studies showed that the highest removal efficiencies were obtained by usage of $\mathrm{NaCl}$ as electrolyte $[8,14]$. Therefore, the $\mathrm{NaCl}$ was used as electrolyte at three different concentrations: $2.5,5.0$ and $10.0 \mathrm{~g} / \mathrm{L}$. the maximum removal efficiencies were obtained for COD and TOC as 43.4 and $42.3 \%$, respectively. The consumed electric energy as 294.81, 218.49 and 169.07 $\mathrm{kWh} / \mathrm{m}^{3}$ and operating cost as $73.7,54.6,42.27 \mathrm{Tl}$ were calculated for $2.5,5.0$ and $10.0 \mathrm{~g} / \mathrm{L}$ of electrolyte concentration, respectively. These results adding $\mathrm{NaCl}$ is not only increase removal efficiencies but also decrease the operation cost. 

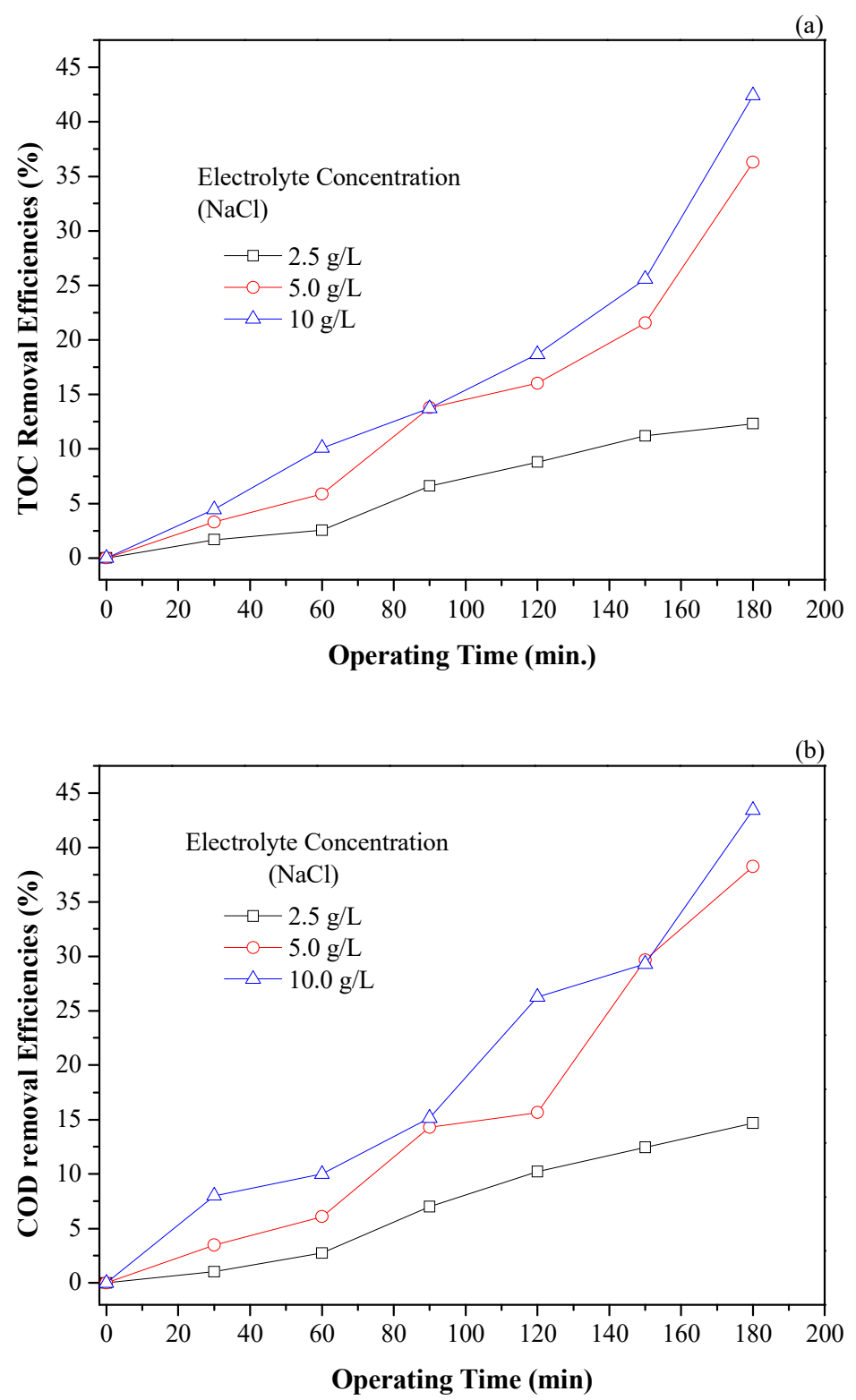

Figure 3. The effect of electrolyte concentration (pH: 3.5 and CD: $100 \mathrm{~mA} / \mathrm{cm}^{2}$ )

Consequently, the main oxidizing agent in this study is seemed as hypochlorite ion or hypochlorous acid produced by chloride ions, which originate from salt $(\mathrm{NaCl})$ used as electrolyte. The other agent is the hydroxyl radical, resulting from unselective and complete mineralization of organic pollutants by EO at the anode surface.

\section{Conclusions}

In this study, highly toxic alkyd resin production wastewater which has high organic content, were treated with the most promising electrode, BDD, by electrooxidation process. The highest 
removal efficiencies was obtained at $100 \mathrm{~mA} / \mathrm{cm}^{2}, \mathrm{pH}$ of $3.5,180 \mathrm{~min}$. and $10 \mathrm{~g} / \mathrm{L}$ electrolyte concentration as $43.4 \%$ for COD and $42.3 \%$ for TOC. The consumed electric energy and operation cost were calculated as $169.07 \mathrm{kWh} / \mathrm{m}^{3}$ and $42.27 \mathrm{TL}$. Although satisfactory COD and TOC removal were not obtained in this study, EO process could be concluded as the most promising treatment system for alkylid resin production wastewater.

\section{References}

[1] O. Tünay, D. Çakır, I. Kabdaş1, Characterization and treatability of alkyd resin production wastewater, Desalin. Water Treat. 101 (2018) 151-156. doi:10.5004/dwt.2018.21761.

[2] E. Gengec, Treatment of highly toxic cardboard plant wastewater by a combination of electrocoagulation and electrooxidation processes, Ecotoxicol. Environ. Saf. 145 (2017). doi:10.1016/j.ecoenv.2017.07.032.

[3] H. Särkkä, A. Bhatnagar, M. Sillanpää, Recent developments of electro-oxidation in water treatment - A review, J. Electroanal. Chem. 754 (2015) 46-56. doi:10.1016/j.jelechem.2015.06.016.

[4] W. Wu, Z.-H. Huang, T.-T. Lim, Recent development of mixed metal oxide anodes for electrochemical oxidation of organic pollutants in water, Appl. Catal. A Gen. 480 (2014) 58-78. doi:http://dx.doi.org/10.1016/j.apcata.2014.04.035.

[5] M. Panizza, G. Cerisola, Removal of organic pollutants from industrial wastewater by electrogenerated Fenton's reagent, Water Res. 35 (2001) 3987-3992. doi:10.1016/S00431354(01)00135-X.

[6] Z. Ukundimana, P.I. Omwene, E. Gengec, O.T. Can, M. Kobya, Electrooxidation as post treatment of ultrafiltration effluent in a landfill leachate MBR treatment plant: Effects of BDD, Pt and DSA anode types, Electrochim. Acta. 286 (2018) 252-263. doi:10.1016/j.electacta.2018.08.019.

[7] O. Scialdone, Electrochemical oxidation of organic pollutants in water at metal oxide electrodes: A simple theoretical model including direct and indirect oxidation processes at the anodic surface, Electrochim. Acta. 54 (2009) 6140-6147. doi:10.1016/j.electacta.2009.05.066.

[8] I. Sires, E. Brillas, M.A. Oturan, M.A. Rodrigo, M. Panizza, Electrochemical advanced oxidation processes: Today and tomorrow. A review, Environ. Sci. Pollut. Res. 21 (2014) 8336-8367. doi:10.1007/s11356-014-2783-1.

[9] W. Gao, J. Chen, X. Guan, R. Jin, F. Zhang, N. Guan, Catalytic reduction of nitrite ions in drinking water over $\mathrm{Pd}-\mathrm{Cu} / \mathrm{TiO} 2$ bimetallic catalyst, 95 (2004) 333-339. doi:10.1016/j.cattod.2004.06.013.

[10] C.A. Martínez-Huitle, S. Ferro, Electrochemical oxidation of organic pollutants for the wastewater treatment: direct and indirect processes., Chem. Soc. Rev. 35 (2006) 1324-40. doi:10.1039/b517632h.

[11] A. Marco Antonio Quiroz, S. Ferro, C.A. Martínez-Huitle, Y.M. Vong, Boron Doped Diamond Electrode for the Wastewater Treatment, J. Braz. Chem. Soc. 17 (2006) 227236.

[12] APHA, Standard Methods for the Examination of Water and Wastewater, 18th ed., American Public Health Association, Washington, DC, 1998.

[13] E. Gengec, M. Kobya, E. Demirbas, A. Akyol, K. Oktor, Optimization of baker's yeast 
wastewater using response surface methodology by electrocoagulation, Desalination. (2012). doi:10.1016/j.desal.2011.11.023.

[14] C. Comninellis, C. Pulgarin, Anodic oxidation of phenol for waste water treatment, J. Appl. Electrochem. 21 (1991) 703-708. doi:10.1007/BF01034049. 